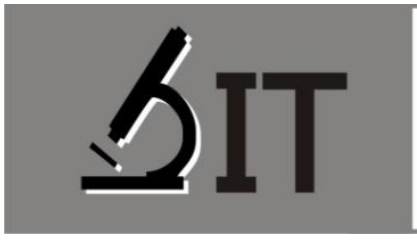

p-ISSN : 2597-8977

e-ISSN : 2597-8985

Iga Selfiamawati*)

Universitas Negeri Makassar

Andi Rahmat Saleh Universitas Negeri Makassar
JIT 4 (2) (2021) 91-96

JURNAL IPA TERPADU

http://ojs.unm.ac.id/index.php/ipaterpadu

\section{PENGEMBANGAN MULTIMEDIA INTERAKTIF BERBASIS LECTORA INSPIRE MATERI STRUKTUR DAN FUNGSI JARINGAN TUMBUHAN SMA KELAS XI}

Abstrak: Pengembangan multimedia interaktif berbasis Lectora Inspire pada materi struktur dan fungsi jaringan tumbuhan bertujuan untuk menghasilkan media pembelajaran yang valid. Jenis penelitian ini adalah penelitian dan pengembangan menggunakan model pengembangan 4-D yang terdiri atas pendefenisian, perancangan, pengembangan, dan penyebarluasan. Multimedia yang dikembangkan berupa gambar, teks, video, animasi, dan evaluasi yang tergabung dalam aplikasi bernama Lectora Inspire. Uji validasi produk dilakukan oleh dua orang validator ahli berupa instrumen penelitian multimedia interaktif. Hasil validator ahli menunjukkan bahwa produk yang dikembangkan layak digunakan sebagai nilai instrumen penilaian multimedia interaktif sebesar 4,24. Berdasarkan hasil penelitian dapat disimpulkan bahwa pengembangan multimedia interaktif pada struktur dan fungsi jaringan tumbuhan adalah valid.

Kata Kunci: Multimedia interaktif, Penelitian dan Pengembangan, 4-D, Lectora Inspire, Valid.

Abstract : The development of interactive multimedia based on Lectora Inspire in structure and function of plant tissue aims to produce a learning media that is valid. This research is a type of Research and Development (R\&D) using 4-D development model, which has included define, design, develop, and disseminate. Interactive Multimedia developed in the form of images, text, videos, animations and evaluation are incorporated in an application called Lectora Inspire. The product validity test was carried out by two expert validators in the form of interactive multimedia assessment instrument. The results of the expert validators have showed that the products developed in deserves to be used as the value of interactive Multimedia assessment instrument of 4.24. Based on the results of this study it can be concluded that the development of interactive multimedia in structure and function of plant tissue was valid.

Keyword: Interactive Multimedia, , Research And Development (R \& D), 4D, Lectora Inspire, Valid.

*) Correspondence Author: igaselfi@gmail.com 


\section{PENDAHULUAN}

Proses belajar mengajar yang terjadi di sekolah merupakan salah satu bentuk komunikasi. Proses komunikasi yang berlangsung terjadi antara guru dan peserta didik. Melalui komunikasi, pesan dimungkinkan bisa diserap oleh semua orang. Demikian halnya dalam proses komunikasi perlu digunakan sarana dalam proses mengajar yang membantu proses komunikasi yang disebut media. Media pembelajaran merupakan komponen integral dari sistem pembelajaran. Tanpa media pembelajaran, proses belajar mengajar itu tidak dapat terjadi (Sahid, 2012). Pedoman pemilihan sumber belajar adalah dengan menganalisis pernyataan-pernyataan, yaitu: (1) bahwa sumber belajar yang dipilih sesuai dengan tujuan pembelajaran, (2) sumber belajar apa yang tersedia secara fisik bagi pebelajar. (3) sumber belajar yang paling aman digunakan oleh pelajar. (4) bahwa sumber belajar yang dipilih dapat meningkatkan motivasi belajar. (5) bahwa penggunaan sumber belajar tertentu karena mendapat tekanan atau paksaan dari pihak tertentu (Caladine \& Richard, 2008).

Penerapan integrasi Teknologi Informasi dan Komunikasi (TIK) dalam konteks akademik menyebabkan perubahan dalam cara belajar mengajar (Gays dkk, 2009). Penciptaan inovasi, teknologi dan sumber daya informasi modern dalam pendidikan sebagai kreasi pengetahuan dapat digunakan dalam pembelajaran khususnya bagi peserta didik IT mendorong para guru untuk mengubah metode pengajaran menggunakan metode dan sumber belajar yang lebih efektif (Voloshyna \& Glazunova, 2014; Ilomäki \& Lakkala, 2018). Hal ini senada dengan pendapat (Camelo, Torres, Reche, \& Costa, 2018), menyatakan bahwa perlu menerapkan metode pengajaran baru untuk mempromosikan integrasi TIK dalam ruang kelas dengan cara yang lebih baik dan menarik bagi peserta didik.

Sanjaya (2012) menyatakan bahwa, salah satu multimedia yang paling mendukung dalam proses pembelajaran yaitu multimedia interaktif. Multimedia interaktif merupakan multimedia yang tidak bersifat linier, namun peserta didik memiliki pilihan sesuai dengan menu yang ditawarkan. Pembelajaran berbasis multimedia adalah kegiatan pembelajaran yang memanfaatkan komputer untuk membuat dan menggabungkan teks, grafik, audio, gambar bergerak (video dan animasi) dengan menggabungkan link dan tool yang memungkinkan pemakai untuk melakukan navigasi, berinteraksi, berkreasi, dan berkomunikasi dari berbagai ragam dan bentuk dari media pembelajaran (Rusman et al, 2011).

Anleigh, dkk (1996) mengemukakan bahwa aplikasi multimedia seperti presentasi, training, dan pemberian informasi memerlukan penggunaan gambar yang bergerak seperti video dan animasi, berikut suara yang ditampilkan bersama image dan teks. Pembelajaran multimedia interaktif pada penelitian ini akan menggunakan sebuah software yaitu Software Lector alnspire. Lectora inspire adalah perangkat lunak authoring tool yang dikembangkan oleh Trivatis Corporation yang didirikan oleh Timothy D. Loudermik di Cincinnati, Ohio. Lectora Inspireini dirilis tahun 1999. Lectora Inspire memiliki tampilan yang sudah tidak asing kita yang telah mengenal maupun menguasai Microsoft Office.

Model pengembangan yang digunakan adalah model pengembangan 4-D yang dikemukakan oleh Thiagiarajan dalam Trianto (2007), terdiri atas 4 tahap utama, yang terdiri atas: (1) Define (tahap pendefenisian), (2) Design (tahap Perancangan), (3) Develop (tahap Pengembangan) (4) Disseminate (tahap penyebarluasan). Berdasarkan penelitian yang dilakukan oleh Kusumawati (2016) diketahui bahwa kesulitan yang dihadapi peserta didik dalam belajar struktur dan fungsi jaringan tumbuhan terdiri dari 3 ranah yaitu: (1) ranah memahami struktur jaringan tumbuhan, (2) fungsi jaringan tumbuhan, dan (3) hubungan struktur dan jaringan. Berdasarkan uraian tersebut, maka peneliti mengadakan penelitian dengan judul "pengembangan multimedia interaktif berbasis Lectora Inspire materi struktur dan fungsi jaringan tumbuhan SMA kelas XI". 


\section{METODE}

Jenis penelitian yang digunakan adalah penelitian dan pengembangan (Research and Development) yaitu pengembangan multimedia interaktif pada materi struktur dan fungsi jaringan tumbuhan SMA kelas XI. Model pengembangan multimedia interaktif ini menggunakan model 4-D yang memiliki empat tahapan yakni define, design, develop, disseminate. Penelitian ini dilaksanakan hanya sampai pada tahap develop. Analisis kebutuhan peserta didik dilakukan pada bulan Agustus. Produk yang telah dikembangkan oleh peneliti selanjutnya dinilai oleh dua validator ahli untuk menguji validitas produk. Pengumpulan data dilakukan dengan cara pengisian angket oleh dua validator ahli yang selanjutnya dianalisis melalui Microsoft excel.

Kriteria yang digunakan untuk menentukan kategori kevalidan multimedia interaktif dapat dilihat pada Tabel 1 berikut.

Tabel 1. Kriteria Tingkat Kevalidan

\begin{tabular}{cc}
\hline Nilai & Keterangan \\
\hline $4,5 \leq \boldsymbol{V}_{\boldsymbol{a}}=5$ & Sangat valid \\
$3,5 \leq \boldsymbol{V}_{\boldsymbol{a}}<4,5$ & Valid \\
$2,5 \leq \boldsymbol{V}_{\boldsymbol{a}}$ a $<3,5$ & Kurang valid \\
$1,5 \leq \boldsymbol{V}_{\boldsymbol{a}}<2,5$ & Tidak valid \\
$\boldsymbol{V}_{\boldsymbol{a}}<1,5$ & Sangat tidak valid \\
\hline
\end{tabular}

\section{HASIL DAN PEMBAHASAN}

\section{Hasil}

Penelitian pengembangan yang dilakukan menghasilkan produk berupa multimedia interaktif yang valid. Adapun hasil analisis uji validitas produk sebagai berikut.

\section{a. Uji Validitas}

Validasi multimedia interaktif dilakukan beberapa kali hingga diperoleh multimedia yang benar valid dan layak untuk digunakan berupa lembar validasi yang nantinya divalidasi oleh validator ahli.

Lembar validasi multimedia interaktif berbasis Lectora Inspire berupa instrumen penilaian validator ahli yang digunakan untuk memperoleh data tentang penilaian dari ahli terhadap multimedia interaktif. Adapun hasil dari penilaian validator ahli terhadap multimedia interaktif terdapat pada Tabel 2 berikut. 
Tabel 2. Penilaian Validator Ahli Terhadap Multimedia Interaktif

\begin{tabular}{cccc}
\hline No. & Aspek yang Dinilai & Rata-rata Aspek $\left(\overline{A_{i}}\right)$ & Keterangan \\
\hline 1. & Sajian pembelajaran & 4,2 & Valid \\
2. & Kelayakan isi & 4,08 & Valid \\
3. & Desain & 4,4 & Valid \\
4. & Bahas & 4,5 & Valid \\
& Rata-rata $\left(V_{a}\right)$ & 4,24 & Valid \\
\hline
\end{tabular}

\section{Pembahasan}

Hasil observasi di kelas XI SMAN 8 Makassar diperoleh bahwa media pembelajaran yang biasa digunakan berupa buku pegangan peserta didik. Sehingga, guru dan peserta didik membutuhkan media selain buku pegangan peserta didik untuk menunjang proses belajar mengajar di kelas. Salah satu media yang dapat menjadi pilihan adalah media pembelajaran multimedia interaktif. Hasil penelitian Moreno (1998) menunjukkan bahwa belajar dengan multimedia interaktif lebih baik dari media lain.

Penggunaan multimedia interaktif berbasis Lectora Inspire dengan berbagai fitur yang disediakan diharapkan mampu menjadi sebagai salah satu referensi media pembelajaran yang berperan dalam proses belajar mengajar di sekolah khususnya mata pelajaran Biologi SMA kelas XI. Multimedia interaktif berbasis Lectora Inspire ini diharapkan dapat membuat suasana pembelajaran lebih menarik sehingga menghindari peserta didik merasa jenuh. Hal ini dikarenakan peserta didik diberi kesempatan untuk memilih isi setiap komponen pembelajaran yang disajikan, Selain itu fleksibel dalam pemanfaatannya yang bisa di kelas, secara individual atau secara kelompok kecil serta fleksibel penggunaan waktu.

Adapun dari segi kehandalan fitur, semua tombol navigasi berfungsi dengan baik tanpa ada kendala. Penggunaan ikon dan simbol pada Lectora Inspire yang sederhana sehingga mudah dikenali dan mudah digunakan. Lectora Inspire biologi dalam penggunaan tidak membutuhkan waktu yang lama sehingga mengefisienkan waktu pembelajaran. Lectora Inspire juga dianggap oleh validator dapat membantu siswa dalam belajar mandiri, serta dapat mencapai tujuan pembelajaran. Hal ini selaras dengan pernyataan harapan yang jelas terkait dalam pemanfaatan sumber belajar, Falahuddin (2014) menyatakan bahwa dalam proses belajar mengajar dapat meningkatkan motivasi dan keinginan baru, membangkitkan motivasi dan rangsangan belajar, serta membawa pengaruhpengaruh positif pada psikologis terhadap peserta didik. Oleh karena itu guru diarahkan agar memanfaatkan teknologi dalam merancang sumber belajar untuk meningkatkan motivasi belajar peserta didik.

Setelah mengembangkan multimedia interaktif berbasis Lectora Inspire , kemudian dilakukan uji validitas oleh dua validator ahli. Uji kevalidan multimedia interaktif dilakukan oleh dua validator ahli dengan menilai setiap aspek penilaian yang terdapat pada lembar penilaian dan membandingkan setiap aspek dengan produk yang dikembangkan. Multimedia yang mencapai nilai valid tersebut dapat dinyatakan layak untuk digunakan oleh peserta didik maupun guru. Nilai validitas multimedia interaktif sebesar 4,24. Berdasarkan data tersebut dapat disimpulkan bahwa multimedia interaktif bersifat valid dengan kriteria kevalidan $3,5 \leq{ }_{V_{a}} \leq 4,5$.

Proses penelitian yang dilakukan tidak selalu berjalan sesuai dengan yang direncanakan. Peneliti mengalami beberapa kendala yang membuat produk yang dikembangkan tidak terselesaikan sebagaimana waktu yang direncanakan. Penelitian ini pada awalnya direncanakan akan dilakukan sampai uji kepraktisan, tetapi karena adanya pandemi covid 19, sehingga tidak 
memungkinkan sampai tahap uji kepraktisan di sekolah. Maka, penelitian ini hanya sampai uji validitas oleh dua validator ahli.

\section{KESIMPULAN}

Berdasarkan hasil penelitian yang telah dilaksanakan, maka dapat disimpulkan bahwa multimedia interaktif berbasis Lectora Inspire pada materi struktur dan fungsi jaringan tumbuhan kelas XI SMA bersifat valid dengan nilai validitas 4,24 yang memenuhi standar kevalidan pada kategori $3,5 \leq V_{a}<4,5$.

\section{DAFTAR PUSTAKA}

Anleigh, P., \& Kiran Thakar. (1996). Multimedia Systems Design. Upper Saddle River, NJ: Prentice Hall PTR.

Caladine, \& Richard. (2008). Enhancing E-Learning with Media-Rich Content and Interactions. Hershey: Information Science Publishing.

Camelo, G. E. H., Torres, J. M. T., Reche, M. P. C., \& Costa, R. S. (2018). Using and integration of ict in a diverse educational context of Santander (Colombia). Journal of Technology and Science Education, 8(4), 254-267. https://doi.org/10.3926/jotse.314.

Falahuddin, I. (2014). Pemanfaatan Media dalam Pembelajaran. 1(4), 104-117.

Gays, Mills, \& Airasian. (2009). Educational Research : Competencies for analysis and application-9th. Ed. New Jersey: Merril-Pearson Education.

Ilomäki, L., \& Lakkala, M. (2018). Digital Technology and Practices for School Improvement: Innovative Digital School Model. Research and Practice in Technology Enhanced Learning, 13(1). https://doi.org/10.1186/s41039-018-0094-8.

Moreno, R., \& Mayer, R.E. (1998), A Learner-Centered Approach To Multimedia Explanations: Deriving Instructional Design Principles From Cognitive Theory. Interactive Multimedia Electronic Journal of Computer-Enhanced Learning. (online). (http://imej.wfu.edu/articles/2000/2/05/ index.asp -).Diakses 5 Januari 2021.

Rusman, Kurniawan, D., \& Riyana, C. (2011). Pembelajaran Berbasis Teknologi dan Komunikasi. Jakarta: PT. Raja Grafindo Persada (GP) Press Jakarta.

Sahid. (2012). Pengembangan Media Berbasis ICT. Retrieved from http://staff.uny.ac.id/sites/default/files/131930136/Pengembangan Media Pembelajaran Berbasis ICT.Pdf.

Sanjaya, W. (2012). Media Komunikasi Pembelajaran. Jakarta. Retrieved from PT. Fajar Interpratama Mandiri.

Sidik, B. (2014). Pemrograman Web dengan Php. Solo: Santika Kencana.

Trianto. (2007). Model Pembelajaran Terpadu dalam Teori dan Praktek. Surabaya: Pustaka Ilmu.

Voloshyna, T., \& Glazunova, O. (2014). Types of Academic Internet-Resources for It Students' Individual Work Management. Information Technologies in Education, (21), 78-86. https://doi.org/10.14308/ite000513. 


\section{Iga Selfiamawati}

Mahasiswa Jurusan Biologi FMIPA Universitas Negeri Makassar, dapat dihubungi melalui email: igaselfi@gmail.com

\section{Andi Rahmat Saleh}

Dosen Jurusan Biologi FMIPA Universitas Negeri Makassar, Aktif dalam penelitian keterampilan berpikir, model pembelajaran, dan pengembangan media interaktif dalam pembelajaran. Dapat dihubungi melalui email: andirahmatsaleh@unm.ac.id. 